University of Nebraska - Lincoln

DigitalCommons@University of Nebraska - Lincoln

April 2005

\title{
Readings in Place: Recent Publications in Southwestern Literature and Studies
}

Thomas Lynch

University of Nebraska - Lincoln, tlynch2@unl.edu

Follow this and additional works at: https://digitalcommons.unl.edu/englishfacpubs

Part of the English Language and Literature Commons

Lynch, Thomas, "Readings in Place: Recent Publications in Southwestern Literature and Studies" (2005). Faculty Publications -- Department of English. 32.

https://digitalcommons.unl.edu/englishfacpubs/32

This Article is brought to you for free and open access by the English, Department of at DigitalCommons@University of Nebraska - Lincoln. It has been accepted for inclusion in Faculty Publications -- Department of English by an authorized administrator of DigitalCommons@University of Nebraska - Lincoln. 


\title{
Readings in Place: Recent Publications in Southwestern Literature and Studies
}

\author{
Tom Lynch
}

Defining the region known as the Southwest is a project that keeps many geographers pleasantly and securely employed. As D. W. Meinig famously quipped, "The Southwest is a distinctive place to the American mind but a somewhat blurred place on American maps, which is to say that everyone knows that there is a Southwest but there is little agreement as to just where it is" (3). In spite of the great variability, complexity, and subjectivity of definitions geographers promulgate, however, when one distills the matter the region is nearly always defined along the intersection of two axes, one cultural and the other natural.

Certain characteristics of these two axes are obvious in the six works considered here. Culturally, the region is most distinguished from the rest of the US by the existence of two enduring ethnic communities, the indigenous and the Hispanic, with the presence of the Mexican border exerting a powerful influence. In very different ways, Molly H. Mullin's Culture in the Market Place: Gender, Art, and Value in the American Southwest, Audrey Goodman's Translating Southwestern Landscapes: The Making of an Anglo Literary Region, and J. Douglas Canfield's Mavericks on the Border: The Early Southwest in Historical Fiction and Film address themselves to the influence of these indigenous and Hispano-Mexican communities and, especially, to the cultural and symbolic function they serve for their Anglo neighbors.

On the natural axis, aridity is the inescapable fact of life. Most of the region receives between four and sixteen inches of rain a year. Aridity - efforts to adapt to it and attempts to overcome itunderlies much of the region's politics and culture. Aridity generates most of the region's other distinctive natural characteristics as well, such as the unique flora and fauna, the stark ruggedness of the mountains, the dramatic visibility of the geologic strata, even the character of the light that so enamors artists. David N. Cassuto's
Culture in the Marketplace: Gender, Art, and Value in the American Southwest. By Molly H. Mullin. Duke University Press, 2001.

Translating Southwestern Landscapes: The Making of an Anglo Literary Region. By Audrey Goodman. University of Arizona Press, 2002.

Mavericks on the Border: The Early Southwest in Historical Fiction and Film. By J. Douglas Canfield. University Press of Kentucky, 2001.

Dripping Dry: Literature, Politics, and Water in the Desert Southwest. By David N. Cassuto. University of Michigan Press, 2001. 
Getting over the Color Green: Contemporary Environmental Literature of the Southwest. Edited by Scott Slovic. University of Arizona Press, 2001.

\section{The Last Cheater's} Waltz: Beauty and Violence in the Desert Southwest. By Ellen Meloy. University of Arizona Press, 1999.
Dripping Dry: Literature, Politics, and Water in the Desert Southwest, Scott Slovic's edited collection Getting Over the Color Green: Contemporary Environmental Literature of the Southwest, and Ellen Meloy's The Last Cheater's Waltz: Beauty and Violence in the Desert Southwest are all, in their different ways, considerations of aridity and its cultural and natural implications.

Santa $\mathrm{Fe}$ is both a town and a synecdoche for a regionally defining cultural style. Though the town takes pains to preserve its authenticity, debunking it has become almost a cliché in cultural studies. Santa Fe presents an easy target. It's a wondrous nexus of the authentic and the hokey, of the ancient, indigenous, and intriguingly vernacular with the faddish, exotic, and appallingly kitschy. As one of the oldest European communities in North America, founded in 1609, situated near some of the oldest continuously inhabited Native American communities, the Rio Grande Pueblos, Santa Fe can make a legitimate claim to an enduring integrity. Yet there is something artificial about its authenticity, something too calculated about its tastefulness, as though it were a sort of southwestern Williamsburg, inauthentic precisely because of its efforts to fossilize its authenticity.

However, while deconstructing and disparaging Santa $\mathrm{Fe}$ has become a delightful subspecialty for cultural studies scholars, it is a process that remains quite irrelevant to most of the town's residents and visitors. Mullin's Culture in the Marketplace explores this chasm between the scholarly critique, and the popular embrace, of Santa Fe's culture. (The book's subtitle uses the term "Southwest," but it is exclusively concerned with Santa Fe.) Mullin notes the irony of "the increasing popularity of ideas and sensibilities historically associated with anthropology, such as one is likely to see in Santa Fe tourism, at a time when anthropologists and scholars in related fields have been subjecting those very same notions to sustained critique and revision" (2).

Mullin defines her project as an effort to "examine the "culturalization of difference' and the social construction of value in relation to the patronage of American Indian art in New Mexico from the early twentieth century to the present day" (3). She does this by studying a network of well-educated white women, a network that includes well-known writers such as Mary Austin and Willa Cather; but Mullin is especially interested in lesser-known figures, especially Elizabeth Shepley Sergeant, Margretta Stewart Dietrich, and the sisters Elizabeth and Martha White. These women moved to Santa Fe during the 1920s and established themselves as promoters, arbiters, and consumers of Native American art. Mullin argues: "In their promotion of American Indian arts these women saw themselves as championing new ways of thinking about art in gener- 
al, about culture, and about the continent's Native inhabitants. To members of this network, notions of culture associated with anthropology served as a valuable tool in a number of interrelated struggles - struggles to redefine American national identity; to bridge the separation of public and private, male and female spheres of influence; to gain public influence and authority for themselves; and to construct authoritative standards of value in a society increasingly oriented around the consumption of commodities" (4). Mullin challenges the popular and at least mildly misogynistic image that denigrates these women as simply isolated and eccentric spinsters with too much money and too much idle time in which to spend it. Far from being isolated and insignificant, these women were part of a well-connected cultural community that believed that the Southwest, especially northern New Mexico, had "important and highly promising possibilities for the project of redefining the nation's identity" (27). And their legacy, however dubious in some regards, continues to exert a powerful influence on the region.

In the minds of most people today, the Southwest is not associated with gender freedom and sexual liberation, but Mullin points out how liberating a place it could be for these women. Sergeant, for example, "constructs the West as a place where expectations of gender can be transgressed without penalty" (49). Homosexuality is perhaps the most obvious expression of this liberation of gender identity and "many of the women connected with this particular network of women were lesbians" (73). The aspirations of these women, however, went far beyond personal liberation; they desired a rectification of American identity as a whole that reconfigured the relationship between gender and nationalism. "The Southwest appealed to both Sergeant and Cather," Mullin argues, "in part because it offered a way of reinventing the geography of national identity and of gender in ways that seemed especially promising" (39). For these women, the Southwest, or at least Santa Fe, was a place where one could lead a truly authentic life, both personally and sexually.

And, at a time when industrialism and the consumer-driven market economy were altering the economic landscape, Santa $\mathrm{Fe}$ was also a place where one could, or so it seemed, interact with an authentic, pre-industrial economy. Indeed, to these women, Santa Fe seemed to offer an antidote to the many troubles that ailed the modern world. This is typified by their response to Indian arts. "For many American intellectuals," Mullin contends, "objects made by Indians were especially attractive because they were thought to represent nonalienated labor, a merging of the utilitarian and the creative, art and community, community undivided by class and the distinctions of taste ensuing from mass consumption" (93). 
Mullin's study of the Indian art market is especially valuable for braiding the past with the present and for integrating her own complex and ambiguous responses. Even as she is analyzing and, to some degree, debunking the market in Indian arts and crafts, she is also clearly fond of it. While scholarly, her writing maintains a useful personal narrative style and so she manages to avoid the aloof, sometimes snide tone that permeates many similar works of postmodern cultural analysis. During her time conducting research in Santa Fe, she witnesses the continuity between the ostensible objects of her study - that early network of women - and the contemporary women she is associating with and, to a degree, even herself. She admits that during her time in Santa Fe, she "was reminded of how much the Southwest, especially Northern New Mexico, continues to be perceived by many as a place to achieve self-realization and a healing of body and soul....As in the Whites' day, the area continues to be perceived as a relatively tolerant place with regard to gender and sexuality; I had met a number of gay men and lesbians who said they moved to the city at least in part because of its gay community. Another common thread between the past and present arrivals in Santa Fe seemed to me to reside in a preoccupation with the value and revaluing of commodities" (175-76).

The one significant weakness I found in the book lies in its skirting of the issue of the response of the region's indigenous and Hispano residents to the ministrations of these newcomers. Mullin doesn't entirely ignore the issue, but, although it constitutes some of the more interesting material in the book, it is often found in endnotes rather than in the text. For example, she relates in a note that "Alfonso Ortiz told me that as a young man at San Juan Pueblo he resented some of the patrons discussed here who "thought they knew everything about Indians.' That resentment, he surmised, was part of what inspired him to pursue a career as an anthropologist" (195). One would like to see more of this, and to see it more fully integrated into the analysis. Mullin might, for example, have discussed Cleofas Jaramillo, a native of Arroyo Hondo, who expressed annoyance at "these smart Americans" who make money writing and lecturing about Hispano culture while the members of that culture "sit back and listen" (173). In response, Jaramillo began her own organization, La Sociedad Folklórica, an organization dedicated to the preservation of Hispano customs. I realize that the main focus of Mullin's book is on the role of particular white women, but the consequence of too exclusive a focus on them is to mute the response of the Hispano and Native peoples. Given the stereotyping of these groups as passive and indolent in the face of Anglo energy and initiative, writers who deal with these matters should take special pains not to further such stereotypes, even inadvertently. 
Goodman's Translating Southwestern Landscapes looks at the Southwest during this same historical era. Like Mullin, Goodman explores how recent Anglo arrivals in the Southwest sought to achieve authority over both the landscape and the indigenous and Hispano cultures. However, while Mullin looked primarily at artists and art patrons, Goodman analyzes the cultural work of writers in defining and fostering the idea of the Southwest. Goodman describes her project as one that "reimagines the Southwest at the turn of the twentieth century as a space shaped by the antinomies of American modernity, a site of competing landscapes and translation practices" (xiii). The antinomies she addresses include "the forces of capitalist expansion that lowered spatial barriers only to create a demand for diverse places; the rise of corporate, scientific, and artistic specialization as well as a psychology of individuation, reinvention, and escape; and formulations of American 'high culture' in response to the domination of mass audiences in every field" (xiii).

The book focuses on five major figures: Charles Fletcher Lummis, Zane Grey, Paul Strand, Mary Austin, and Cather. Linking these disparate personalities, Goodman attempts to show "how the collaborative - and often imagined - relation between native inhabitant and regionalist writer seemed to demand of each writer perpetual shifts in genre or transformations of literary form" (xvii). "Each figure," she contends, "occupied a different position in the cultural field," and she shows "how each used the experience of Southwestern spaces and history either to blur formal and generic boundaries or to invent new literary categories" (xvii).

In a manner that correlates well with Mullin's analysis, Goodman describes how the Southwest was a particularly potent battleground in the struggle between modernism and antimodernism in the cultural realm, and between fantasy and reality in the realm of personal desires. "Beginning in the 1880s, Anglo-American writers and photographers," she argues, "projected themselves into the Southwest's many landscapes and documented the meeting of promised and actual experience." However, she continues, "[T]heir simultaneous dependence on the region's economic development and rhetorical resistance to it have correctly been deemed hypocritical and identified as imperialist nostalgia." "Antimodernist ideology and colonial comforts," she concludes, "unquestionably reinforced one another; as a result, the incorporation of the Southwest into the United States has consistently been articulated through discourses of loss" (xiv). While some critics might have ended here, disdainfully dismissing these Anglo writers as hypocritical promulgators of imperial nostalgia, Goodman realizes that it is not so simple. She recognizes something more potentially favorable in their efforts, contending that "we might also in- 
terpret this rhetorical resistance to the region's modernization as a sign that Anglos feared a homogeneous future. Southwestern spaces seemed to promise knowledge of native cultures; if these spaces were destroyed, such knowledge would pass away" (xiv). The discourse of loss, it would seem, was not entirely misguided.

Her discussion of Lummis is especially refreshing. Lummis has lately taken a beating from scholars, and, though Goodman is well aware of his weaknesses, she seeks to rescue what is of most value in his work. She begins with Lummis, she explains, because "his writing and critical reception reveal the complicity between aesthetic production and capitalist expansion in the Southwest" (xviii). And she later elaborates that "Lummis struggled to translate the intensity of his own regional contact into collective expressions of longing for rugged cross-cultural experience, and as he did so, he sustained the tension between history and fantasy that defines modern experience and the literature of the Anglo Southwest" (6). Acknowledging the complexity of his project, Goodman proposes that "Lummis's stories and translations begin to invent a new, postfrontier West that is both authentic and enchanted" (29). Discovering the right formulations by which to blend this ambivalent mix of authenticity and enchantment remains one of the principle tasks of Southwestern writers.

In her discussion of Grey, Goodman extends this theme of contradiction and ambivalence by using Grey to consider "the symbolic production of space" in which Grey's work seeks to "sustain the contradictions and intimate the utopian possibilities of America's most distinctive landscape" (xviii). Though the literary genre Grey helped to create, the Western, is often dismissed as ideologically reactionary and aesthetically superficial, Goodman proposes that "the Western's simultaneous construction of imperial innocence and pursuit of an inner spirituality makes it a modernist quest and encourages us to read it as an extension of the aesthetics and ideology more commonly associated with high culture" (xviii).

Goodman explores how Grey raises a number of important issues in his writing, only to discard them and hence evade their radical implications as his plots develop according to formula. "We have seen that Grey's symbolic spaces acquire new meanings," she summarizes, "as they engage with religious challenges, social crises, economic conflicts, or sexual awakenings, even if these meanings are finally discarded or suppressed by the plot" (66). She identifies three key features that Grey raises but then evades: "the community that integrates work and spiritual belief; the woman empowered by property, economic responsibility, or practical skill; the mutual admiration and dependence between an Indian and an Anglo man" (66). Goodman links Grey with the other writers she considers, writ- 
ers with whom he might seem to have little in common, by concluding that "nearly all Southwestern writers pursued one or more of these utopian ideas, often articulating them, as Grey did, through the landscape or appropriating them through native cultures" (66).

In her chapter on photography, Goodman provides a history of Southwestern photography, beginning with Carleton Watkins and William Henry Jackson and concluding with Ansel Adams, Paul Strand, and Alex Harris. This chapter might seem out of place in a work that otherwise focuses on writers, but Goodman justifies its inclusion by arguing that the chapter "offers an alternate and perhaps more concise account of the transition from turn-of-the-century popular culture to the high culture of the 1920s" (67).

Drawing upon the theories of Walter Benjamin, Goodman analyzes how these photographers express in the visible realm what the writers attempt to create through language, most notably a sense of aura. She argues that modernist photographers such as Strand and Adams, in their evocations of a sense of place, attempt to invoke an invented aura that inheres not in the place itself, not in the landscape nor in the people, but in the mechanics of their presentation of it and, perhaps more importantly, in their desires for it.

She asks whether "all Anglo images necessarily perpetuate a modernist aura of purity" (102). And she answers her own question with a decisive "no" by considering the work of contemporary photographer Alex Harris: “Alex Harris's photographic work in northern New Mexico," Goodman argues, "envisions one alternative to a mechanically produced sense of place that we might take as a model of how landscape, local tradition, and vernacular art interact in the Southwest" (102). In particular, she interprets Harris's low-rider series, a collection of photographs taken from the backseats of low-rider automobiles that use the view out the front windshield to frame the vernacular landscape. In these sorts of photographs, Goodman argues, Harris manages to do what has evaded the other photographers - and the other writers - she considers in her book. He does not impose an outsider's perspective and a cultivated modernist aura on the scenes he presents but instead makes "local preferences not only visible, but dominant" (105). This discussion of Harris's work is insightful and important for what it suggests about the possibilities of Southwestern artists and writers, and my only reservation is that nowhere in the book does she include a similar analysis of contemporary writers whose work might be considered analogous to Harris's photographs.

Her book concludes, instead, with a return to two earlier twentieth-century writers, Austin and Cather. Though Austin's work had been long ignored, recent scholarship, especially feminist, multicultural, and ecocritical work, has found much of interest in Austin's 
writing, and Goodman's book continues the project of moving Austin from the margins to a more prominent position in the literary canon.

"Austin's writing," she argues, "persistently figures the Anglo body as the site where regional knowledge is produced" and, therefore, "it heightens the tension between perception and representation and raises issues that are critical to our interpretation of this period in Southwestern literary history" (108). Goodman specifically identifies three questions posed by Austin's work: "What kind of knowledge must an outsider have in order to be true to a place and its native peoples? Are sincere intentions sufficient defense against charges of cultural appropriation? How thoroughly must traditional materials be transformed before they constitute an entirely different kind of art?" (108). In raising these questions, Austin engages with the ambivalent tension that permeates writing about the Southwest and "articulates the region's high modernist problematic even as she promotes an emerging Southwestern authenticity" (108).

In her consideration of Cather, Goodman contrasts Cather's Great Plains novels with her Southwestern ones. The Nebraska novels, she argues, "initiate a poetics of place that provides access to local knowledge without claiming full possession," whereas the Southwestern works "test the experience of the present (figured in the language of the body or in images) against an awareness of the past (figured as abandoned artifacts or geological formations). Each of Cather's novels thus engages in an anti-modern quest to re-enchant American spaces" (xix-xx).

In a study that analyzes the relationship between insider and outsider perspectives, between native inhabitant and regionalist writers, and that has Austin and Cather in adjacent chapters, one might have anticipated some consideration of Austin's criticism of Cather's most famous Southwestern novel, Death Comes for the Archbishop (1927). Cather visited the Southwest as a guest of Austin's and wrote portions of the novel in Austin's house in Santa Fe. Austin, however, felt the novel betrayed both her own hospitality and that of the Southwest. Adopting the posture of a New Mexico insider, Austin expressed outrage at Cather's portrayal of Padre Antonio José Martinez as a corrupt villain. Padre Martínez has long been revered as a hero in New Mexico for, among other things, his valiant defense of Hispano rights following the Anglo conquest, and historian David Lavender castigates Cather for her slanderous portrayal of him, a slander that still rankles in northern New Mexico. Lavender argues that Cather "obscured the true nature of the difficulties involved in the working out of an accommodation between the vanquished Hispanic peoples of the Southwest and their American conquerors" (Lavender 68). In its portrayal of Hispano New Mexicans as passive victims of cor- 
rupt leaders like Padre Martínez, Cather's novel overtly justifies colonialism. This issue might have provided Goodman an excellent opportunity to pursue many of the issues her book addresses in the context of the conflict between Austin and Cather, and I lament what seems a missed opportunity.

While the book is, overall, an important contribution, I have several reservations. In particular, the book operates with an underlying assumption that the experience of Anglos in the Southwest is always and uniquely suspect. Goodman seems unable to imagine Anglos not just as tourists or consumers but as legitimate Southwesterners. By focusing on the modernist era, when most Anglos in the Southwest were newcomers, she avoids having to see Anglos as legitimate residents of the region. She hints at some possibilities in her discussion of Harris's photographs but overall fails to imagine the possibility that during the past 150 years at least a few Anglos might have successfully negotiated the translation from foreigners to something resembling natives. Indeed, even in her consideration of Harris, she praises him for adopting a local Hispano perspective (viewing the world from a low-rider) rather than for having any unique or credible perspective of his own.

Until recently, Santa Fe has been definitive of the Southwest (as the conflation of Santa Fe with "the Southwest" in the subtitle of Mullin's book indicates); however, it is being displaced by a location more congenial to postmodern theories and sensibilities: "the Border."

Mullin has suggested how the malleability of identity in Santa Fe was liberating to a group of elite women; however, in Mavericks on the Border, Canfield explores how that same flexibility of identity along the border, that same sort of rubbing elbows with otherness, can lead not to a sense of an authentic and harmonious life but to existential uncertainty and crisis. In his acknowledgments, Canfield explains that he is concerned with "how twentieth-century authors and film-makers have repeatedly placed protagonists in these Southwest Borderlands facing existential crises of identity and ideology" (7). He grants his indebtedness to borderland theorists such as Gloria Anzaldúa and José Saldívar, but then contrasts his own work with theirs: "Unlike other recent books in border studies," he says, "this is not a book about the border as a liminal space for Chicanos.... I am trying to tell another part of that story borrowing critical concepts from Anzaldúa and others. But mine is not a coherent narrative. It follows no archetype from oppression and exclusion to resistance and liberation" (7). Instead, Canfield is interested in what he calls "a pantheon of mavericks, many historically based, all imaginatively conceived as straddling a cultural cusp representative of excruciating dilemma. I have called them existential heroes" (2). 
In these Borderlands, Canfield argues, "protagonists of extraordinary consciousness come face to face with the void, with a cosmos without essence, without essential meaning, free from the sovereignty of mind. Tragic art is born from this shock and its attendant pain" (4). However, he does not speculate whether this sensation is a trait of all border regions, or if it is a unique response to the US-Mexico border. Compelling questions are brought to mind. For example, are similar works with comparable existential heroes written on the USCanada border, or, in fact, on any other international borders in the world? If not, why not? Is there something distinctive about the US border with Mexico that makes it especially suitable for the production of existential heroes? One can infer some answers to these questions, but Canfield doesn't directly address them.

Canfield's subtitle uses the word maverick, a term he applies to every protagonist he discusses. These characters are unbranded, masterless, and, while in American popular ideology this ought to lead them to a sense of freedom, according to Canfield it provokes instead an existential dilemma. Unlike the women Mullin writes about, who can claim new identities when they cross over into the new land of Santa Fe, when Canfield's heroes on the border cross over to a new land their identity is undermined, forcing them to an awareness of the constructedness of self, an insight which, rather than liberating them, terrifies.

One wonders if this existential crisis is not, in fact, provoked by the desert landscape itself, across which the borderline is only incidental. In Canfield's reading, the vast desert landscape strips the protagonists of markers of identity, leaves them alone with God, with Nature, or, more likely, with nada. The desert, then, functions a bit like a spare stage set in a play by Samuel Beckett. This is a compelling vision and, no doubt, Canfield is correct that it is the view of many of the works he discusses, but there is also something disturbingly ethnocentric and unecological about it. So I am troubled by Canfield's too easy acceptance of the landscape as symbolic of an existential void. One sees the desert as a bleak existential landscape not because in reality it is one but because of one's ignorance of its biotic abundance and complexity, because one believes, as one's culture has taught one to believe, that landscapes must be green to be meaningful and pleasant.

Canfield concludes with the claim that works such as these "that place their protagonists on the border do so because the artists want to portray crises of identity, ideology, conscience in the rich French sense of more than conscience but consciousness itself. The vast spaces, the sparseness, the harshness, the paradoxical beauty of the place alone prompt such crises without the conflicts that have raged here" (211). I'll grant him the truth of this statement for the writers 
he considers, but I am hesitant to generalize beyond them. I wonder, for example, about those who write about the borderland not because they want to portray existential crises of identity but because it's where they live and what they know. For writers such as Pat Mora, say, or Denise Chavez, the border is not a challenge to their identity, it is their identity. But Canfield's approach does not allow one to imagine such a possibility.

Canfield considers an interesting and eclectic range of writers and a variety of films. He mixes canonical and noncanonical works, high culture with middlebrow. His book is, I think, most important for simultaneously analyzing works by both American and Mexican writers. In this, he implicitly questions the notion of a national literature. How appropriate is such a nationalistic configuration today, especially, but not exclusively, in the border region? In a world marked by the decline of national identities, in a world redolent with various forms of globalism, one looks, mostly in vain, for less nationalism in the study and teaching of literature. Along the border one hears much talk of writing, indeed of living, sin fronteras, without borders. And there is a strong sense among some people that a unique borderlands culture is emerging, neither American nor Mexican, but a complex hybrid of the two. But, for the most part, literary study still stops at the border. Canfield's book is a valuable counter to this and suggests some useful approaches toward a true literary study sin fronteras.

While Canfield's book sees the desert landscapes of the border as a stage set for existential drama, the final three books examined here prompt us to see the region as a complex of natural ecosystems and to consider the process of coming to terms with living in the arid Southwest not as an existential void but as a home.

Echoing John Wesley Powell and Wallace Stegner, Cassuto begins Dripping Dry with this bold claim: "More than any other single characteristic, aridity defines the American West. It has shaped the land west of the hundredth meridian, the components of the social contract enacted among its inhabitants, and the compact between the inhabitants and the land" (1). His book analyzes four novels in the context of aridity and the control of water: Austin's The Ford (1917), John Steinbeck's The Grapes of Wrath (1939), Edward Abbey's The Monkey Wrench Gang (1975), and Barbara Kingsolver's Animal Dreams (1990).

Each of the novels he addresses, Cassuto argues, exemplifies a different period in our national orientation to the control of water: "Examined collectively, the four works present a composite portrait of Reclamation. And Reclamation, I will argue, is one of the most important cultural and ecological phenomena in this nation's history" (2). Cassuto divides the Reclamation era into five stages 
and devotes a chapter of his book to each. His first chapter deals with Powell's "vision of a 'reclaimed' West populated by family farms whose size and crops were determined by the realities of arid-lands agriculture" (123).

After laying this foundation, Cassuto uses the four novels to exemplify each of the four stages of Reclamation. Austin's The Ford, he argues, "shows the heady optimism of Reclamation's early years and the clash between urban and rural constituencies even while both claimed to represent the same values" (123). Steinbeck's Grapes of Wrath, then, "takes place during the heyday of the Reclamation era, when water, dams, and delivery mechanisms trumped all other concerns, including human rights and the health of the ecosystem. Corporate agriculture co-opted yeoman symbolism and used it to enormous personal gain" (123). Due to the hubris and corruption of Reclamation, Cassuto argues, "conflict was unavoidable" (123). And Abbey's Monkey Wrench Gang "reflects a growing disillusionment with reclamation for its own sake and a willingness to privilege environmental concerns over economic benefit" (123). Finally, Cassutto contends, Kingsolver's Animal Dreams "dramatizes Reclamation's end phase. It depicts a population struggling to disrupt and replace the cycle of corporate gain, environmental degradation, and hydraulic dependency created by nine decades of Reclamation rhetoric" (123).

While this book points in some fruitful directions and presents some valuable insights, it is weakened by a serious lack of knowledge of the irrigation technologies of the Hispano Southwest. Cassuto posits, for example, that "the Spanish explorers who first traversed the Southwest deemed it an inhospitable wasteland, unfit for human settlement except by savages content to scrape their existences from the unforgiving rock" (58). This claim, rather bafflingly, ignores 400 years of Spanish settlement and the unique Chicano agropastoral culture that evolved in the arid West. For several hundred years the Hispano settlers in northern New Mexico have practiced a low-tech and, arguably, environmentally benign form of irrigation known as the acequia system. No consideration of European cultural adaptations to aridity and to the use of water in the American West can afford to ignore this distinctive cultural evolution. Considerable scholarship on this agropastoral irrigation system is available. And novels such as Frank Waters's People of the Valley (1941) and John Nichols's The Milagro Beanfield War (1974) directly address the acequia system and the threats posed to it by the sort of Reclamation programs Cassuto is considering. I realize Cassuto is limiting himself to a few novels, but even Austin's The Ford and Kingsolver's Animal Dreams deal with Hispano irrigation techniques and so would provide appropriate opportunity to discuss this system. 
Another argument I have with Cassuto is with the contrast he emphasizes between what he calls restoration and sustainability. He repeatedly describes advocates of restoration, such as Abbey, as concerned with recreating a "pristine" natural state, in contrast to advocates of sustainability, such as Kingsolver, who more wisely recognize that human influences on nature are unavoidable. Cassuto's definition of restoration, however, is drawn from the most extreme and implausible form; it certainly is not like any of the restoration efforts I'm aware of and seems not to be informed by extensive recent work in conservation biology and environmental history. In his criticism of Abbey's desire to dismantle Glen Canyon Dam and to restore the free flow of the Colorado River, the basic plot of The Monkey Wrench Gang, Cassuto counters that Abbey's vision is flawed because, "Restoration's goal of remaking pristine ecosystems...looms as an impossible goal, comparable to unmaking glass into sand. Furthermore, if healthy ecosystems exist in a constant state of flux, which 'pristine' state should they reoccupy?" (122). This argument sounds persuasive until one notices that Cassuto never quotes a single advocate of restoration-not Abbey, and not anyone else - using the term pristine. We have here a classic straw-man fallacy. Certainly Abbey realizes, even in this highly idealistic novel, that destroying Glen Canyon Dam will not magically remake a pristine ecosystem. And certainly conservation biologists and environmental historians who advocate ecological restoration are well aware of the issues Cassuto raises. Usually this "pristine" canard is raised from the political right as a way to challenge all forms of environmentalism, and it is surprising to see it employed in a study whose ostensible desire is to further, not to hinder, efforts to protect the natural environment.

Many of the works gathered in Slovic's anthology Getting over the Color Green attempt to get at some of the same themes as Cassuto's work, what Stegner called a "westernization of the perceptions" (54). People living in the arid West and Southwest live in a landscape that could hardly be more different from the small, rainy, foggy island on which their language, literary tradition, and inherited aesthetic sensibilities developed. The title of Slovic's collection is drawn from Stegner's claim that to live in the West "you have to get over the color green; you have to quit associating beauty with gardens and lawns" (54). The many essays Slovic has gathered attempt to nudge us along such an aesthetic evolution, and they suggest something of the role literature can play in creating a truly inhabitory culture in the arid West. In this regard the works he has compiled and the vision of the Southwest they create contrasts both with Canfield's sense of deserts as spare existential wastelands and with Goodman's unstated implication that Anglos cannot become authentic residents of the Southwest. 
Slovic describes his collection as providing "for the first time, a collection of excellent contemporary writing about nature from the greater Southwest, spanning several genres (nonfiction, field notes, fiction, and poetry) and more than half a dozen states" (xv). As Slovic acknowledges, his book follows on the heels of Peter Wild's earlier Desert Reader (1991), and so Slovic focuses only on writing published since 1990. His anthology includes such well-known authors as Rudolfo Anaya, Kingsolver, and Nichols, as well as newer writers whose work is primarily in nature writing, such as Janice Emily Bowers, Sharman Apt Russell, and Ken Lamberton.

Slovic argues that in the final decades of the twentieth century "there was a flowering of important writing about the relationship between human beings and the natural world," and he suggests that this flowering was especially vibrant in the arid Southwest (xv$\mathrm{xvi}$ ). This volume is testimony to the truth of his assertion. Slovic might be accused of bias, but I think he is accurate in proposing that environmental writing underwent a blossoming in the latter twentieth century, to the degree that it can now confidently be claimed to represent an important strain in American literature. Indeed, nature writing has long been an important and distinctive genre of American literature since at least the mid-nineteenth century. Yet, except for Henry David Thoreau's work, this genre is entirely shut out of the literary canon, even the diverse, multicultural, and overtly politicized canon. To those who consider them important, it is remarkable that such writers as John Muir, John Burroughs, Aldo Leopold, Rachel Carson, Wendell Berry, Abbey, Annie Dillard, and Barry Lopez - to name only some of the most notable - fail to appear in any of the readily available and most widely taught anthologies of American literature. And while I'm on this tack, Stegner, too, whose own writing is outstanding and whose influence on new writing from the American West and on thinking about the relationship between place and culture is pervasive, is similarly excluded from the canon. One is hard pressed to explain this neglect other than by a pervasive regional bias among the canon makers or by an ignorance that borders on the obtuse. No anthology of American literature that excludes writers such as Stegner, Muir, Abbey, Lopez, or Carson can truly be called inclusive.

The Southwest is both an ecologically and culturally diverse place, and Slovic makes an effort to reflect both of those sorts of diversities. One might reasonably argue, however, that his definition of the Southwest is too broad: "I think of the Southwest as anywhere in the United States (and perhaps Mexico)," he proposes, "where the general hue of the land is more brown than green, where one's lips crack from dryness and sweat dries almost instantly, and where cactus or tumbleweed or sagebrush abound. Or where it's so dry, or the 
drop-offs so sheer, that nothing grows at all" (xxi). In this he admits to describing an arid region much larger than the "Southwest," including states such as the Dakotas, Montana, Idaho, and eastern portions of Washington and Oregon. Admittedly, defining the boundaries of the Southwest is subjective and imprecise, but surely the term loses all meaning when extended to the state of Washington, and one might prefer a more accurate subtitle referring, perhaps, to the "arid West," which would include, but not be limited to, the Southwest.

Slovic's book is divided into four sections: "Watching Closely: Forays in Natural History," "Risking Experience: Adventures in the Wild," "Living Close to the Land," and "Taking a Stand: Voices of Conservation and Restoration." Within these categories, the ethnic distinctions are interesting and suggest quite distinct orientations to the land. For instance, the "Living Close to the Land" section has by far the greatest number of indigenous and Hispanic voices, and Benjamin Saenz's essay "Cebolleros," about picking onions, is the only selection in the book that envisions work as a way of connecting to nature: "I bowed my head, bent my back toward the earth again - toward the earth and the onions" (254). Throughout most of the collection, hiking, rafting, and camping themes dominate, and these selections are almost exclusively written by Anglo authors.

I was also struck by the degree to which the collection suggests that nature is nonurban and that matters of environmental interest are found exclusively outside of town. Only Nichols's essay "A Traffic Violation" really addresses the problem of sprawl, surely one of the more pressing environmental issues in the region. I don't know, however, how much to hold Slovic responsible for this neglect of the urban environment and how much it betrays the tendencies and biases of the region's nature writers in general. Nevertheless, reading this collection of environmental writing one would never suspect that the environment in which most Southwesterners live is highly urban.

These sorts of quibbles aside, the book does present important points. A recurrent theme is the atomic Southwest. It is amazing how many works of Southwestern literature engage, at least peripherally, with nuclear matters. In Slovic's anthology, numerous essays, stories, and poems, such as Rudolfo Anaya's "Devil Deer" and Lisa Gerber's "Witness," deal directly with the presence of the atomic industry in the Southwest. The existence of places like the Los Alamos weapons laboratories, the Trinity Site, the Nevada Test Site, and the many uranium mines and mill tailings clashes with the common view of the region as a pre-industrial, bucolic backwater far removed from the travails of modern life.

This contrast between the splendor of the landscape and the presence of the nuclear industry is the focus of Meloy's Last 
Cheater's Waltz, notably subtitled Beauty and Violence in the Desert Southwest. Meloy was not included in Slovic's anthology, but she is firmly in the tradition of those writers and could well have been included. Her writing typifies a coming to terms with living in the West, which she envisions as a diminished but still astonishingly beautiful place.

The book opens with Meloy in her house along the San Juan River in southeastern Utah. While making her morning coffee, she accidentally boils a lizard in her mug. This event spurs her to escape a psychic malaise she has recently fallen into. The book spins from the psyche of the inner self outward onto the landscape and attempts to map the turbulence that erupts where the two eddy and churn into each other. Wondering about her place in the world, Meloy ponders a relief map of the Colorado Plateau: "My home lay in its heart, the southeastern Utah portion of the Four Corners, where the borders of Utah, Colorado, New Mexico, and Arizona meet. It is a geography of infinite cycles, of stolid pulses of emergence and subsidence, which, in terms geologic and human, is the story of the desert itself" (6). Meloy follows this cyclic pattern throughout the book, engaging in a series of her own emergences and subsidences, excursions and returns. Her ruminations continue, echoing some of the themes also addressed in the previous books considered here:

The region serves up the full paradox of emptiness. It has been considered a void, a 'loathsome' province of little utility to humankind, and a kind of cosmic navel, an inexhaustible well-spring of mystery and spiritual transcendence. Epicures of fecund mists may starve here, but ascetics will not. Mesozoic rivers drown beneath rock and dune. Red sand and prickly history fill your boots, unbidden. The green in winter stays locked in juniper trees on the high mesas, and toads encode their flesh with silver, summer rain. The nights are coal-black and water-deep, the light often too bright to understand. In this abundant space and isolation, the energy lords extract their bounty of natural resources, and the curators of mass destruction once mined their egregious weapons and reckless acts. It is a land of absolutes, of passion and indifference, lush textures, and inscrutable tensions. Here violence can push beauty to the edge of a razor blade.(6-7)

Meloy decides to get reacquainted with this landscape of contrasting absolutes, putting together an atlas that she calls her "Map of the Known Universe." Prodded outward by this map, she begins to traverse the country, refamiliarizing herself with it in an effort to restore some degree of inner peace. She begins with a trip to a 
nearby plateau to see a blossoming stand of claret cup cacti, a plant that, for her, epitomizes the psychic tensions of the landscape with its stunning blossoms embosomed in wicked prickly thorns. Her visit to the cacti gratifies her, but afterwards she encounters a wide graded road she had not known was in the area. "The big road," she says, "ended abruptly at an enormous field of disturbed oil, put back together and recontoured with earth-moving machinery" (18). What she has found is an inept job at the reclamation of a uranium mine. The Southwest may be a land of enchantment, but it is also a land of apocalypse, and encounters such as this don't allow Meloy to wallow in idyllic romanticism. "I was well acquainted," she says, "with the plateau's role, from the early fifties through the seventies, as a major producer of uranium for the cold war's nuclear arsenal. Relics of the uranium mining boom still lingered around the neighborhood. I lived in the continent's most bombed province, where for many years the US Departments of Energy and Defense tested their wars on the western deserts" (20).

Already feeling psychically distressed, she is stunned and dismayed by the violation she sees and even more by what it calls to mind. She wonders, "How was a person to heal her numbed soul amid these fretful, querulous phantoms of mass death? Then I remembered the promise of the boiled lizard: to look closely and burn hotter, to forge the desert's sweetness and ferocity into my own, to find beauty" (21). This is a recurring theme of the book, that the Southwest is a place of contrasting extremes and that one must work hard, expend serious psychological energy, to maintain some degree of internal harmony, to avoid being torn apart by the contrasts. Her encounter with the uranium mine leads her on a quest to "find the valley's missing pieces" (21), a journey into the atomic Southwest, a place she calls in one chapter title "the terrain of strategic death" (23).

Meloy first ventures to the Trinity Site in New Mexico's Jornada del Muerto, the location of the first nuclear explosion. At the bomb site memorial, she reinforces her sense of the region as a land of disconcerting contrasts. "Trinity is simultaneously a geography of nihilistic lunacy and passionate beauty," she says. "It is the locus of my century's strange confluence of deserts and physics, and I am standing on ground zero" (26). Though I've earlier been critical of Canfield's portrayal of the desert as an existential stage set and a place of nullity, the ever-present awareness of the apocalypse in the Southwestern deserts that Meloy experiences certainly reinforces his contention.

Following this journey to the Trinity Site, Meloy returns home to work on her house with her husband and to consider her unkempt patch of land and its ecological history. Near her home lie the ruins 
When reading analyses of regional writers [there is a] point where one usually encounters the, alas, all toocommon phrase "and so-and-so's work is not just regional, it also has universal meaning." . . . these sorts of appeals to the suspect notion of universal significance reek of insecure provincialism; they confirm the very suspicion they seek to counter.

of Ancestral Pueblo (Anasazi) houses. Like many residents in the arid Southwest, Meloy contemplates the ruins of those who have lived here before her. With this awareness, she avoids that false pioneer sense of having been the first to settle in the place. She is, she realizes, only the latest of many waves of settlers, no better, no worse, and no more nor less likely to endure. This is an important awareness to have for cultivating a sense and an ethic of place, for fostering a humble bioregional identity rather than the heroic frontier identity that is more commonly foisted on us by our culture and that is the bane of Western life and, especially, of Western politics.

When reading analyses of regional writers this is the point where one usually encounters the, alas, all-too-common phrase "and so-andso's work is not just regional, it also has universal meaning." But I will avoid making such a claim, for these sorts of appeals to the suspect notion of universal significance reek of insecure provincialism; they confirm the very suspicion they seek to counter. The regionally focused works I've considered here may have a universal significance (whatever that really means), but again they may not. They may be of interest to readers everywhere, not just in the Southwest, but I don't think that matters very much. I understand why commercial forces make this a matter of great interest to some writers and publishers, but I am indifferent to it; there are more important concerns at hand.

Throughout her book Meloy is engaged in what Stegner called "a process of westernization" (54). It is a process that takes not years nor decades nor lifetimes but many generations, is, indeed, never ending, and literature has a vital role to play in this process. Meloy, her neighbors, and the literary and scholarly tradition to which she adds her voice, including those other books considered here, are all engaged in a process of learning to be at home in a landscape for which our cultural heritage has not prepared us. This is a vital, humble task, and, to the degree it is fostered by literature and literary studies, surely more meaningful than grandiose gestures laying claim to suspect universal relevance and appeal.

Tom Lynch is Assistant Professor in the Department of English at the University of Nebraska, Lincoln, where he specializes in literature of the American West and ecocriticism.

\section{Works Cited}

Jaramillo, Cleofas. Romance of a Little Village Girl. San Antonio: Naylor, 1955.

Lavender, David. "The Tyranny of Facts." Old Southwest/New Southwest: Essays on a Region and Its Literature. Ed. Judy Nolte Lensink. Tucson: Tucson Public Library, 1987. 63-73.
Meinig, D. W. Southwest: Three Peoples in Geographical Change: 1600-1970. New York: Oxford UP, 1971.

Stegner, Wallace. "Thoughts in a Dry Land." Where the Bluebird Sings to the Lemonade Springs: Living and Writing in the West. New York: Random, 1992. 